\title{
An Analysis of Trade Relations between the European Union and the Transition Economies of Central and Eastern Europe
}

\author{
Panagiotis Liargovas \\ Athens University \\ Christos Papazoglou \\ University of Crete
}

\begin{abstract}
This paper empirically determines the main factors influencing trade flows between the European Union and the transition economies of Central and Eastern Europe. The analysis relies on the estimation of gravity-type equations for both exports and imports. Besides the basic variables that are normally included in a gravity equation, such as the size of the market, population and distance, two additional variables are included capturing the process of liberal ization and privatization. Our results indicate that the two transition variables constitute important factors responsible for the moderate level of trade integra tion between the transition economies of the Black Sea region (BSEC) and the European Union (EU) member-states. This outcome is in direct conflict with the corresponding results for the more advanced transition economies of Cen tral European Countries (CECS) where the particular variables appear

* Correspondence Address: Panagiotis Liargovas, Athens University of Economics and Business, Department of International and European Economic Studies, Patision 76, Athens 104 34, Greece. Christos Papazoglou, University of Crete, Department of Economics, Rethymno 741 00, and Bank of Greece, Economic Research Division, GR 102 50, Athens, Greece.
\end{abstract}

(O1999 - Institute for International Economics, Sejong Institution. All rights reserved. 
insignificant. This is a reflection of the fact that, contrary to the experience of the BSEC countries, transition policies in the CECs have been proceeded much more vigorously. (JEL Classifications: F15, 052, P51) ४Key Words: transition economies, BSEC, CECS, EU, trade relations, gravity model.>

\section{Introduction}

A common development in all transition economies of Central and Eastern Europe is the dramatic decline of both exports and imports as well as the subsequent geographical reorientation of trade to developed market economies, mainly to the European Union (EU), at the beginning of the transformation process. The product composition of trade among former CMEA members and the composition of trade with the West have also altered substantially, particularly with regard to fuels machinery and chemicals.

Albeit these common characteristics, all transition economies have not experienced the same depth of trade integration with the West and particularly with the European Union. F or example the nine countries in transition which belong to the so-called Black Sea Economic Cooperation Council $(B S E C)^{1}$ have not developed trade flows with the $E U$ to the same degree as the Central European Countries (CECS), namely Czech and Slovak Republics, Hungary, Poland and Slovenia. Table 1 contains information regarding exports and imports of the nine BSEC countries in transition and of the five CECs to and from the EU for the period 1993-1997. Table 2 presents the shares of the two regions in the total amount of exports and imports to and from the EU of the 14 countries in transition taken together. It can be seen that the five CECs accounted for $52.4 \%$ of total exports to the EU and for $51.7 \%$ of total imports from the EU in 1993. For the nine BSEC countries the corresponding shares were $47.6 \%$ and $48.3 \%$ It should be noted that these shares would be much lower in the absence of Russia, which accounts for around $70 \%$ of total BSEC trade. The relative position of

1. The BSEC includes the following countries: Albania, Armenia, Azerbaijan, Bulgaria, Georgia, Greece, M oldova, Romania, the Russian Federation, Turkey and Ukraine. Except for Greece and Turkey, all other countries are transition economies. Our analysis concerns only the transition economies of the region. 
Table 1

Trade Flows between the Transition Economies and the European Union (bil. \$)

\begin{tabular}{l|c|c|c|c|r|r|r|r|r|r|}
\hline & \multicolumn{5}{|c|}{ Exports to the EU } & \multicolumn{5}{|c|}{ Imports from the EU } \\
\cline { 2 - 11 } & 1993 & 1994 & 1995 & 1996 & 1997 & 1993 & 1994 & 1995 & 1996 & 1997 \\
\hline Armenia & 0.01 & 0.03 & 0.05 & 0.1 & 0.1 & 0.04 & 0.1 & 0.1 & 0.2 & 0.2 \\
Azerbaijan & 0.06 & 0.08 & 0.09 & 0 & 0.1 & 0.06 & 0.1 & 0.2 & 0.2 & 0.3 \\
Georgia & 0.04 & 0.01 & 0.04 & 0.0 & 0.1 & 0.1 & 0.1 & 0.2 & 0.2 & 0.2 \\
Russia & 20.4 & 25.1 & 30.2 & 31.0 & 32 & 14.8 & 22.6 & 25.4 & 27.0 & 29.0 \\
M oldova & 0.03 & 0.04 & 0.09 & 0.1 & 0.1 & 0.1 & 0.1 & 0.2 & 0.3 & 0.3 \\
Ukraine & 1.1 & 0.7 & 1.7 & 1.8 & 2.1 & 1.8 & 2.1 & 2.9 & 3.3 & 3.9 \\
Bulgaria & 1.2 & 1.7 & 2.4 & 2.2 & 2.3 & 1.7 & 2.1 & 2.7 & 2.0 & 1.9 \\
Romania & 2.1 & 3.4 & 4.5 & 4.7 & 5.2 & 12.9 & 14.6 & 20.2 & 25.3 & 28.2 \\
Albania & 0.07 & 0.1 & 0.2 & 0.3 & 0.2 & 0.5 & 0.5 & 0.7 & 0.9 & 0.5 \\
Czech R & 6.5 & 8.2 & 11.8 & 12.4 & 13.3 & 8.1 & 10.1 & 15.3 & 17.7 & 17.9 \\
Hungary & 5.7 & 7.3 & 10 & 11.3 & 13.2 & 7.5 & 9.6 & 11.4 & 12.6 & 15.0 \\
Poland & 10.0 & 12.2 & 16.1 & 15.9 & 16.7 & 12.9 & 14.6 & 20.2 & 25.3 & 28.2 \\
Slovak R & 1.6 & 2.7 & 4.0 & 4.3 & 4.5 & 1.6 & 2.7 & 4.0 & 4.3 & 4.5 \\
Slovenia & 3.7 & 4.5 & 5.6 & 5.5 & 5.3 & 4.2 & 5.1 & 6.8 & 6.8 & 7.1 \\
\hline
\end{tabular}

Source: IM F Direction of Trade Statistics, [1998].

BSEC countries got even worse by the end of 1997. That is, although total exports into the EU increased from 52.5 billion dollars to 95.2 billions, the BSEC share was reduced to $44.3 \%$ whereas the CECs share was further increased to $55.7 \%$ Similarly, imports from the EU increased to 137.2 billions dollars in 1997. However, the relative BSEC share was reduced to 47.0\% whereas the CECS share was increased to $53.0 \%$ The above developments raise questions about the factors, which influence trade integration between the EU and the transition economies. The purpose of this paper then is to offer explanations about the different experiences of trade integration with the EU of the transition economies of the Black Sea region and those of Central Europe.

Our main hypothesis is that besides the role of the conventional determinants of trade flows, factors such as the form of privatization process and the progress of economic and institutional reforms, which constitute the 
Table 2

Trade Shares(\%) between the Transition Economies and the European Union

\begin{tabular}{|l|c|c|c|c|c|c|c|c|c|c|}
\hline & \multicolumn{4}{|c|}{ Exports to the EU } & \multicolumn{5}{c|}{ Imports from the EU } \\
\cline { 2 - 11 } & 1993 & 1994 & 1995 & 1996 & 1997 & 1993 & 1994 & 1995 & 1996 & 1997 \\
\hline $\begin{array}{l}\text { BSEC } \\
\text { (\%of total) }\end{array}$ & $47.6 \%$ & $47.2 \%$ & $45.3 \%$ & $44.9 \%$ & $44.3 \%$ & $48.3 \%$ & $50.1 \%$ & $47.7 \%$ & $47.1 \%$ & $47.0 \%$ \\
\hline $\begin{array}{l}\text { CECs } \\
\text { (\%of total) }\end{array}$ & $52.4 \%$ & $52.8 \%$ & $54.7 \%$ & $55.1 \%$ & $55.7 \%$ & $51.7 \%$ & $49.9 \%$ & $52.3 \%$ & $52.9 \%$ & $53.0 \%$ \\
\hline Total(bil. \$) & 52.5 & 66.1 & 86.8 & 89.6 & 95.2 & 66.3 & 84.4 & 110.3 & 126.1 & 137.2 \\
\hline
\end{tabular}

Source: IM F Direction of Trade Statistics, 1998.

essence of the transition process, might be responsible for the disappointing performance of the BSEC countries in stimulating trade flows. Given the fact that the CECs have moved much faster towards a market-based economic system, relative to the BSEC countries, this comparative analysis is of considerable importance in determining the role of the transition process on the bilateral trade.flows.

The analysis relies upon the use of the so-called gravity model. The model was initiated by Linnemann [1966] and introduces three broad determinants that explain the size of a bilateral trade flow. In particular, they refer to the importer's demand, the exporter's supply and the cost, either with respect to transportation or information, associated with international trade. Empirically, these determinants are usually approximated by variables such as income and population of the trading partners as well as the geographical distance between them (Graziani [1992] Havrysyshyn and Pritchett, [1991]). The gravity model has been used by many analysts in order to explain trade patterns in many parts of the world while its theoretical foundation has been extensively discussed in the literature (Bergstrand [1985]).

In our analysis, we introduce two gravity equations (one for exports and one for imports of the transition economies to and from the EU) which are augmented in order to capture the impact of the transition process on the bilateral trade flows. The transition process refers to an array of reforms ranging from institutional to economic measures that aim to replace central 
planning with the rudiments of a market economy. These reforms can be classified into four broad categories that refer to liberalization, private ownership, institutions, and social policies. As we see in the next section, our analysis relies on the degree of liberalization and privatization of the transition economies as proxies for the progress of reform. Of course, other measures of reform such as institutional are also essential for capturing the speed of the transition but they are not easily quantifiable.

The rest of the paper is structured as follows. Section II includes a theoretical framework, based on the gravity model, of the major factors determining trade flows in the transition economies. Estimation and empirical results are presented and analyzed in section III. Finally, section IV concludes our paper and offers some policy implications.

\section{The Gravity Model}

As indicated, we introduce two separate gravity equations one describing exports from the transition countries to the EU and another one describing the corresponding imports. The main reason for doing this is to evaluate the impact of the transition process separately on exports and on imports. M ore specifically, we construct the following equations:

$$
\begin{aligned}
\log X_{i j}= & a_{0}+a_{1} \log Y_{i}+a_{2} \log N_{i}+a_{3} \log Y_{j}+a_{4} \log N_{j}+a_{5} \log D_{i j}+a_{6} \log L I_{i} \\
& +a_{7} \log P I_{i}+\log u_{i j}
\end{aligned}
$$

$\log M_{i j}=b_{0}+b_{1} \log Y_{i}+b_{2} \log N_{i}+b_{3} \log Y_{j}+b_{4} \log N_{j}+b_{5} \log D_{i j}+b_{6} \log L I_{i}$

$$
+b_{7} \log P I_{i}+\log e_{i j}
$$

where,

$X_{i j}=$ value of exports from countr $y i$ to country $j$

$M_{i j}=$ value of imports from countr $y \mathrm{i}$ to country $\mathrm{j}$

$\mathrm{a}_{0}, \mathrm{~b}_{0}=$ constants

$Y_{i}, Y_{j}=$ income of countries $i$ and $j$

$\mathrm{N}_{\mathrm{i}}, \mathrm{N}_{\mathrm{j}}=$ population of countries $\mathrm{i}$ and $\mathrm{j}$

$D_{i j}=$ distance between countries $i$ and $j$ 


$$
\begin{aligned}
& L_{i}=\text { degree of economic liberalization of country } i \\
& \mathrm{PI}_{i}=\text { private sector output as a share of GDP in country } \mathrm{i} \\
& \mathrm{u}_{\mathrm{ij}}, \mathrm{e}_{\mathrm{ij}}=\text { lognormal error terms. }
\end{aligned}
$$

Both equations represent bilateral trade flows. Therefore, exports of country i reflect imports of country j and vice-versa. The first five variables are the basic determinants of the size of bilateral trade flows as Linnemann [1966] introduced them. They represent the exporters' supply, the importers' demand and the cost associated with international trade. The next two variables in both equations introduce the transition process by considering the effect of the liberalization and privatization process on the size of the bilateral trade flows. Thus an important element that describes the current status of most transition economies is incorporated into the analysis.

$M$ ore specifically, in both equations the income and population variables represent endowments and tastes of the trading partners. In particular, for the exporting country the supply of exports depends positively on the production capacity and negatively on the size of the exporting country. The former is captured by GDP while the latter reflects the fact that large countries have greater production capacity which makes them more capable of satisfying their own needs and is proxied by the population of the exporting country. Thus we expect $a_{1}$ to be positive and $a_{2}$ to be negative in equation (1) and $b_{3}$ to be positive and $b_{4}$ to be negative in equation (2).

Turning to the importing country, the demand for imports depends positively on its income and negatively on its population. The former reflects higher demand, while the latter suggests greater self-sufficiency. Thus we expect $a_{3}$ to be positive and $a_{4}$ to be negative in equation ( 1 ) and $b_{1}$ to be positive and $b_{2}$ to be negative in equation (2).

The geographical distance variable, $D_{\mathrm{ij}}$, which appears in both equations, represents resistance to trade. That is, it reflects the various costs either with respect to transportation or information associated with international trade. As a result, we expect $a_{5}$ and $b_{5}$ to be negative.

The transition process is introduced through the incorporation of the degree of liberalization and privatization. This is an important aspect of the transition economies, which makes their initial conditions quite different 
from those of other economies and in particular the developing ones. $M$ ore specifically, most developing countries to a lesser or greater extent have had functioning market economies as well as a large private sector and as result, trade integration with the West involved mainly the liberalization of existing trade regulations (Sader [1993]). Thus, the bulk of trade flows between them and the West was not necessarily linked to the progress of a liberalization or privatization program. In the transition economies of Central and Eastern Europe, on the other hand, the trade regime was characterized by: (a) the small number and insignificant role of bilateral and multilateral trade relations/agreements, (b) the large amount of state trading, (c) the great number of tariff and non-tariff measures in exports and imports, (d) the large share of barter trade transactions, (e) the non-liberalization of the foreign exchange system and ( $f$ ) the power of protectionist lobbies. At the same time, the private sector was almost non-existent. Hence, the growth of trade in these countries, at least in the short-term, could be closely related to the process of reform and liberalization of the economic system as well as to the progress and form of privatization programs.

Liberalization refers to the removal of the total state control on economic transactions and the shifting towards a market - based economic system. It involves the freeing of domestic price and trade, foreign trade and currency convertibility, the entry of new business and private sector development. Liberalization has been positively associated with output as well as trade growth. For trade, in particular, liberalization measures improve the market access both for imports and exports. Any firm without major restrictions then can carry out trade. There is powerful evidence from transition economies that trade liberalization magnify the efficiency and output gains from competing in world markets (World Bank [1996]).

For the countries in transition the challenge is to liberalize their export and import barriers (i.e. export ceilings and bans, export tariffs and duties, export licenses and taxes, export quotas, subsidies, minimum prices, import bans and quotas, tariffs, import licenses, import surcharges, duties and taxes), to liberalize their exchange rate system (i.e. convertibility of the currency for current and capital account transactions), to decrease the share of barter transactions and to de-monopolize their foreign trade activities. Thus, we expect $a_{6}$ and $b_{6}$ to be positive in equations ( 1 ) and ( 2 ) respec- 
Table 3

Privatization and Liberalization by Countly

\begin{tabular}{|l|c|c|}
\hline Country & Priv. Sector* 1997 & Liber. Index** 1997 \\
\hline Albania & 75 & 73 \\
\hline Armenia & 55 & 71 \\
\hline Azerbaijan & 40 & 48 \\
\hline Bulgaria & 50 & 72 \\
\hline Czech Republic & 75 & 85 \\
\hline Georgia & 55 & 69 \\
\hline Hungary & 75 & 82 \\
\hline M oldova & 45 & 70 \\
\hline Poland & 65 & 83 \\
\hline Romania & 60 & 71 \\
\hline Russia & 68 & 70 \\
\hline Slovak Republic & 75 & 85 \\
\hline Slovenia & 58 & 80 \\
\hline Ukraine & 50 & 65 \\
\hline
\end{tabular}

*Private sector output as a share of GDP

**Extent of economic liberalization ( $\%$

Source: EBRD [1997].

tively, capturing the positive impact of liberalization on trade. Table 3 contains information on the economic liberalization of the BSEC and the CE transition economies, with the respective index being a weighted average of estimates of liberalization of domestic transactions, external transactions, and entry of new firms (EBRD [1997]). It is evident that liberalization stands quite low for the BSEC countries as compared to the CECS.

Another important dimension of the transition process is ownership reform. All transition economies have to a lesser or greater extent moved towards private ownership. Decentralization of ownership is the best way to increase competition and improve performance. Thus, the engagement of the private sector in foreign transactions plays a crucial role for the growth of trade in transition economies and the improvement of market access for imports as well as for exports. We then expect $a_{7}$ and $b_{7}$ to be positive in equations (1) and (2) respectively, reflecting the favorable impact of privatization on trade for the transition economies. Table 3 presents evidence as 
regards the private sector output as a share of GDP for these economies. Although all Central and E astern European countries have introduced privatization programs, there are differences in the form and timing of their schemes, which, in turn, may be responsible for the differences in their trade patterns with the EU. The data, even though they refer to privatization of firms as well as entry of new firms, are representative to the consequences of the different privatization programs. Thus, the speed of the privatization process in most countries of the region may be a significant factor affecting the size of trade flows.

\section{Estimation and Empirical Results}

In this section we investigate empirically the main determinants of trade flows by estimating two gravity equations. We use sectoral (cross-countries) data to compute trade flows between the BSEC and CE transition economies and the $15 \mathrm{EU}$ member-states in 1997. For the former countries, the data set includes all nine BSEC transition economies and thus, it consists of 135 observations. For the latter countries, the data set includes all five transition economies trading with $15 \mathrm{EU}$ member-states. Therefore, the number of observations is 75 . Thus, we estimate two gravity equations referring to trade flows between the two regions of transition economies and the EU member-states, for the same year. This will enable us to compare the resulting estimations for the two groups of transition economies and see how the BSEC countries relate to the more advanced CECS.

Tables 4 and 5 report the empirical results of the two gravity equations for exports and imports of the transition economies (BSEC and CECS separately) to and from the $\mathrm{EU}$ member states respectively. We report two equations in each case, whereas the first one includes all proposed independent variables, while the second contains the statistically significant ones only and therefore it represents our preferred equation. The only exception is in the case of BSEC imports from the EU, where we report one equation since all independent variables are statistically significant. We report the values of the coefficients ( $t$-statistics in parenthesis) as well as the values of $R^{2}$ and the Durbin-Watson Statistics. The results can be interpreted as follows.

First, with respect to the conventional variables of the gravity model, we 
Table 4

Empirical Results - Exports to the EU

\begin{tabular}{|l|c|c|c|c|}
\hline \multirow{2}{*}{ Variable } & \multicolumn{2}{|c|}{ BSEC E conomies } & \multicolumn{2}{c|}{ CE Economies } \\
\cline { 2 - 5 } & eq.1 & eq.2 & eq.1 & eq.2 \\
\hline Constant & -69.45 & -68.73 & -47.23 & -56.87 \\
& $(-2.28)$ & $(-2.29)$ & $(-2.19)$ & $(-3.72)$ \\
$\mathrm{LY}_{\mathrm{t}}$ & 1.01 & 0.96 & -0.05 & 1.06 \\
& $(3.74)$ & $(6.35)$ & $(-0.03)$ & $(11.43)$ \\
$\mathrm{LY}_{\mathrm{e}}$ & 8.55 & 8.53 & 6.4 & 6.43 \\
& $(2.64)$ & $(2.66)$ & $(3.7)$ & $(3.77)$ \\
$\mathrm{LN}_{\mathrm{t}}$ & -0.08 & & 0.95 & \\
& $(-0.24)$ & & $(0.63)$ & \\
$\mathrm{LN}_{\mathrm{e}}$ & -7.91 & -7.89 & -5.84 & -5.81 \\
& $(-2.41)$ & $(-2.43)$ & $(-3.28)$ & $(-3.33)$ \\
$\mathrm{LD}$ & -2.11 & -2.13 & -1.47 & -1.46 \\
$\mathrm{te}$ & $(-7.12)$ & $(-7.54)$ & $(-14.87)$ & $(-15.26)$ \\
$\mathrm{LLI}$ & 5.92 & 5.72 & 1.85 & \\
& $(3.72)$ & $(4.33)$ & $(0.66)$ & \\
$\mathrm{LPI}$ & 2.02 & 1.95 & -2.99 & \\
& $(2.08)$ & $(2.13)$ & $(-0.62)$ & \\
\hline $\mathrm{R}^{2}$ & 0.93 & 0.93 & 0.91 & 0.91 \\
$\mathrm{Adj} . \mathrm{R}^{2}$ & 0.91 & 0.91 & 0.90 & 0.90 \\
$\mathrm{D}-\mathrm{W}$ & 1.98 & 1.99 & 1.98 & 1.96 \\
\hline
\end{tabular}

$L Y_{t}=G D P$ of Transition economy, $L Y_{e}=G D P$ of $E U$ member state, $L N_{t}=$ Population of transition economy, $L_{\mathrm{e}}=$ population of $E U$ member state, $L D_{\text {te }}=D$ istance between transition country and $\mathrm{EU}$ member state, $\mathrm{LLI}=\mathrm{Liberalization}$ index, $\mathrm{LPI}=$ Privatization index. All variables are expressed in logarithms and this is indicated by the capital letter $L$ in front of each variable. D ata sources are the IM F trade statistics (export and import flows), EBRD (liberalization and privatization index), Eurostat (GDP, population) and World Atlas (distances of capitals).

see that the GDP of the transition economies, the European GDP, the European population as well as the distance variable have the correct signs and they are statistically significant in all gravity equations. The variable for the population of the transition economies appears significant in the equations for imports, while it is insignificant in the equations for exports for both the 
Table 5

Empirical Results - Imports from the EU

\begin{tabular}{|c|c|c|c|}
\hline \multirow{2}{*}{ Variable } & \multirow{2}{*}{$\frac{\text { BSEC Economies }}{\text { eq.1 }}$} & \multicolumn{2}{|c|}{ CE Economies } \\
\hline & & eq.1 & eq.2 \\
\hline \multirow[t]{2}{*}{ Constant } & -62.71 & -63.06 & -59.03 \\
\hline & $(-2.69)$ & $(-2.49)$ & $(-3.43)$ \\
\hline \multirow{2}{*}{$L Y_{t}$} & 1.13 & 1.91 & 1.49 \\
\hline & (5.74) & (0.99) & (6.17) \\
\hline \multirow[t]{2}{*}{$L Y_{e}$} & 7.73 & 6.28 & 6.23 \\
\hline & (3.06) & (3.24) & (3.29) \\
\hline \multirow[t]{2}{*}{$\mathrm{LN}_{\mathrm{t}}$} & -0.58 & -0.85 & -0.47 \\
\hline & $(-2.26)$ & $(-0.5)$ & $(-2.56)$ \\
\hline \multirow[t]{2}{*}{$\mathrm{LN}_{\mathrm{e}}$} & -7.21 & -5.83 & -5.78 \\
\hline & $(-2.79)$ & $(-2.94)$ & $(-2.98)$ \\
\hline \multirow[t]{2}{*}{$\mathrm{LD}_{\text {te }}$} & -1.08 & -1.23 & -1.23 \\
\hline & $(-6.9)$ & $(-12.29)$ & $(-12.54)$ \\
\hline \multirow[t]{2}{*}{ LLI } & 4.73 & -7.1 & \\
\hline & (3.87) & $(-0.21)$ & \\
\hline \multirow[t]{2}{*}{ LPI } & 2.16 & 1.22 & \\
\hline & (3. 19) & $(0.22)$ & \\
\hline$R^{2}$ & 0.91 & 0.89 & 0.89 \\
\hline Adj. $R^{2}$ & 0.89 & 0.87 & 0.88 \\
\hline$D-W$ & 1.94 & 2.22 & 2.22 \\
\hline
\end{tabular}

$L Y_{t}=G D P$ of Transition economy, $L Y_{e}=G D P$ of EU member state, $L N_{t}=$ Population of transition economy, $\mathrm{LN}_{\mathrm{e}}=$ population of $\mathrm{EU}$ member state, $\mathrm{LD}_{\mathrm{te}}=\mathrm{D}$ istance between transition country and EU member state, $L L I=$ Liberalization index, $L P I=$ Privatization index. All variables are expressed in logarithms and this is indicated by the capital letter $L$ in front of each variable. Data sources are the IM $F$ trade statistics (export and import flows), EBRD (liberalization and privatization index), Eurostat (GDP, population) and World Atlas (distances of capitals).

BSEC and the CE economies. Thus, as far as the conventional variables of the gravity model is concerned, the bilateral trade flows of the BSEC and the CECS vis-a-vis the EU member-states exhibit the same pattern.

Turning to the importance of the transition process, however, the results show quite different trade patterns for the two regions. While the liberaliza- 
tion and privatization indices are important determinants of export and import growth between the BSEC economies and the EU, they do not appear to be significant in the respective equations for the CE economies. Thus, with respect to the role of these two transition variables, the two regions exhibit quite an opposite behavior. This manifests the fact that, by the end of 1997 and after more than six years of transition, the transformation process in the BSEC countries has not proceeded vigorously enough, while in the case of the $\mathrm{CE}$ economies it has proceeded fast and it is almost complete. As a result, factors related to the transition process are still significant determinants of trade flows in the case of BSEC economies, but not in the case of the CE economies.

\section{Conclusions and Policy Proposals}

In this paper we empirically determined the main factors influencing trade flows between the transition countries and the EU member-states. Since 1993 trade flows between the two regions accelerated fast. The gradual liberalization of trade policies, including the decrease in the number of tariff and non-tariff measures in exports and imports, the decline in the share of barter trade transactions and the demonopolization of state trading, the liberalization of the exchange rate, including the convertibility of the current account transactions and finally the development of bilateral and multilateral trade agreements have resulted in the dramatic increase in the growth rates of trade flows.

However, when the transition economies are distinguished between the CECS and the BSEC, it becomes apparent that the two groups have not experienced the same degree of trade integration with the West and particularly with the European Union. This is manifested by the fact that the BSEC countries' shares in total trade with the European Union are lower than the corresponding CECs shares and rather decreasing over time.

By estimating a number of Gravity-type augmented equations we were able to locate the significance of alternative variables, which affect BSEC and CEEC trade with the EU. More specifically, we found that BSEC-EU trade is largely determined by two sets of factors. The first set refers to the timing and form of privatization and to the process of liberalization, which 
constitute factors primarily associated with the transition process. The other set contains factors that are normally included in a gravity model, such as the size of the market, population and distance. In the case of trade flows between the $C E$ economies and the $E U$, on the other hand, only the second set of variables appears to have a significant impact. The fact that the transition variables are not significant in these countries reflects a higher degree of progress in the transition process.

According to our results, inadequate institutional and economic reforms represent significant factors that prevent trade integration. $M$ ore specifically, our results indicate that the two transition variables capturing the progress of the transformation process constitute important factors responsible for the moderate level of trade integration between the transition economies of the Black Sea region and the European U nion member-states. This outcome is in direct conflict with the corresponding results for the more advanced transition economies of Central European Countries where the particular variables appear insignificant. This is a reflection of the fact that, contrary to the experience of the BSEC countries, transition policies in the CECs have been proceeded much more vigorously.

\section{References}

Bergstrand, H.J . [1985], "The Gravity Equation in International Trade: Some Microeconomic Foundations and Empirical Evidence," The Review of Economics and Statistics 67; 474-481.

European Bank for Reconstruction and Development [1994, 1995, 1996 and 1997], Transition Report, EBRD.

Graziani, G. [1992], "Trade Patterns and Specialization of Central and Eastern Europe in EC M arkets," Paper Presented at IIASA Conference on International Trade and Restructuring in Eastern Europe, Laxenburg, Austria, N ovember.

Grossack, I.M . [1965], "Towards an Integration of Static and Dynamic M easures of Industry Concentration," The Review of Economics and Statis tics.

Harylsyshyn, Oleh and Lant Pritchett [1991], "E uropean Trade Patterns after the Transition," Policy Research Working Paper N o. 748, World 
Bank, Washington, D.C.

Krugman, P. [1995], "International Trade Theory and Policy," in G. Grossman and K. Rogoff (eds.) Handbook of International Economics III, Elsevier, North Holland.

Linnemann, Hans [1966], An Econometric Study of International Trade Flows, Amsterdam: North - Holland Publishing Company.

Sader, F. [1993], "Privitization and Foreign Direct Investment in the Developing World, 1988-1992," Working paper Series 13 (1202), World Bank.

World Bank [1996], "From Plan to Market," World Development Report, United Nations Development Program. 